\title{
NEW SPIRIT AND NEW HERO: HOW HUNGARIAN STARTUPS REDEFINE THE IDEAS OF LOCAL CAPITALISM
}

\author{
NATASA SZABÓ 1
}

\begin{abstract}
The present paper investigates how the Bridge Budapest, a CSR organization founded by leading Hungarian IT startups, attempts to shape the values of Hungarian society towards capitalism in general, and towards entrepreneurship in particular. In my paper I argue that the central aim of the organization is to facilitate Hungary's catching up with the core capitalist countries through the transformation of the attitudes and the ideologies surrounding capitalism in the Hungarian context, i.e. the local spirit of capitalism. This consists, on the one hand, of restoring the legitimation of some of the core institutions of capitalism, such as the enterprise and the entrepreneur, and of confronting the risk-taking, innovative and ethical figure of the entrepreneur hero with the provincial figure of the 'postcommunist cheater'. On the other hand, it also consists of propagating a new management of work that aims to produce self-controlling and self-motivating employees. In the narrative of Bridge Budapest IT companies appear as the perfect moral and economic subjects - the bearers of the new spirit of capitalism - that have the expertise to offer solutions to the problems of Hungarian society, and around which the local capitalism should be built.
\end{abstract}

Keywords: startups, ideology, digital capitalism, management of work, entrepreneurship, post-politics

\section{Introduction ${ }^{2}$}

Startups, defined by the U.S. Small Business Administration (U.S. Small Business Administration, n.d.) as typically technology oriented businesses with high growth potential, are the cutting-edge industries of the core capitalist countries. However, in the second half of the 2000s, these knowledge-intensive

1 Student at Central European University and at the College for Advanced Studies in Social Theory (TEK), e-mail: nati.szabo@gmail.com

${ }^{2}$ A version of this paper has previously appeared in Hungarian: Szabó Natasa (2016). A magyar startupok és a kapitalizmus új szelleme: a morális és gazdasági felzárkózás stratégiája a félperiférián. Replika, 99(4.):109-125. 
and innovation-centred companies appeared on the semi-periphery of the global economy in Hungary. Today the key actors of the Hungarian startup scene are Prezi, Ustream, LogMeIn and NNG. It would be quite natural to ask on what basis we are defining these start-ups as Hungarian, because Prezi and Ustream have their headquarters both in Budapest and in San Francisco, while LogMeIn's headquarter is located in Boston. The common trait of these companies is nevertheless that they were partly or totally founded by Hungarians, and regardless of where and for which markets they produce, their public initiatives are focusing on Hungary.

In the last years several public initiatives have been launched by these startups, such as Nyitottak vagyunk (We are Open), ${ }^{3}$ Így dolgozunk mi (We work like this) ${ }^{4}$ and Bridge Budapest. ${ }^{5}$ The common characteristic of these initiatives is that they are reflecting on the Hungarian social context and are directly addressing different parts or groups of the Hungarian society. On the one hand, these projects could be interpreted as part of these companies' corporate social responsibility (CSR) strategies, because through them the startups can make a positive appearance to their social and economic environment. On the other hand, through these public initiatives the startup companies are also producing knowledge and narratives about the Hungarian society and capitalism, and also about themselves. The aim of this research is to contribute to the critical sociological understanding of this new phenomenon by embedding it into the local social context. I believe that this is important for several reasons. First, because in the public sphere the dominant discourses on startup companies are currently shaped mostly by the startups themselves. However, it is important to analyse these narratives from a critical angle, by taking into account the positions and interests of these companies. Second, it is worthwhile to reflect on the role that startups play in the semi-peripheral context and to understand how this context shapes their vision on the local society and capitalism.

In my research I use the Bridge Budapest Association as a case study through which I investigate the relationship of the startup companies with the local society. I chose Bridge Budapest as a case study for two reasons: first, because the founders of the Association are the most successful Hungarian startup companies, which are influential in the Hungarian public sphere and have the potential to shape public discourses. Secondly, because they do not miss this opportunity: Prezi, Ustream and LogMeIn consciously created Bridge Budapest in order to communicate their social values through it. Therefore

\footnotetext{
${ }^{3}$ http://nyitottakvagyunk.hu/hu/

4 http://www.igydolgozunkmi.hu/

${ }^{5}$ http://bridgebudapest.org/
} 
Bridge Budapest is suitable for investigating the founder startup companies' discourses on the Hungarian society, capitalism, and on their own social role. My first research question seeks to investigate what kind of narratives are produced by Bridge Budapest on the Hungarian society and capitalism, while my second research question asks how the Association represents the ideal society and capitalism, and how it tries to realize these representation in the local context.

I used two types of sources for this research: the public materials available on the website of Bridge Budapest, and semi-structured interviews that I conducted with the key figures of the Association. My interviewees were Veronika Pistyur, the CEO of Bridge Budapest, Balázs Varró, the Communications manager of Ustream, and Csaba Faix, the International Communications manager of Prezi. I selected them based on the fact that the projects of Bridge Budapest are managed by the CEO of the Association and by the communications managers of the participating companies. As my aim was to investigate the startups' discourses on the local society and on their own social role, I focused only on their own narratives and self-representation, and I did not analyse media appearances, or other external representations of the Association. My reason to interview the communications managers was also that their tasks include the transmission of their companies' official narratives concerning the Association, its goals and social role. Of course, this does not mean that the positions of the communications managers are not subjective. However, subjectivity should not cause a methodological problem, because on the one hand they are personally involved in the operation of Bridge Budapest, and on the other, because their person and communication - due to their positions - are approved by their companies. Apart from Bridge Budapest's CEO and the communications managers I also interviewed Bence Tordai, who was a participant of the Association's programme Bridge Builders. This was necessary because there is very little public information available concerning the training happening during the programme. I did not conduct interviews with the other participants because my goal was to gain information about the structure of the programme and not the detailed investigation of the participants' experiences.

\section{The Bridge Budapest Association}

The Bridge Budapest Association was founded in 2013 by Prezi, Ustream and LogMeIn, and a year later NNG joined the project. According to their selfdefinition, the common trait of these companies is that they are quickly developing internationally successful companies, emerging from Budapest (Bridge Budapest, n.d.). 
Prezi develops presentation software, NNG offers navigational and infotainmenttechnology, while LogMeln offers cloud-based remote connectivity services. The Association is funded by the participating companies and by private individuals. The president of Bridge Budapest is Péter Árvai, the co-founder and the CEO of Prezi, while the Association's CEO is Veronika Pistyur. The programmes of the Association are developed by Pistyur in cooperation with the communications managers of the participating startups. The programmes of the Bridge Budapest are approved by the Board. The Board, formed by Péter Árvai, Péter Halácsy and Ádám Somlai-Fischer, founders of Prezi, by Gyula Fehér, co-founder of Ustream, by Márton Anka, founder of LogMeIn, and by Péter Balogh, co-founder of NNG has a meeting every three months. Besides them, Stephen J. Luczo (Seagate Technology), is also a board-member, although Seagate Technology as a company does not participate in the work of the Bridge Budapest Association.

The idea of the Association dates back to 2011, and according to Veronika Pistyur the proposal came from Prezi, more specifically from Péter Árvai and Juli Pécsi. The motivation to found Bridge Budapest was that they

did not understand why is there a contrast between the world of their companies and that of the streets, and they did not understand why are people walking with their heads down, why are they afflicted by a malaise, why are they always looking for excuses, and why referencing to circumstances is the first reaction to anything instead of a solution-focused approach? (Interview with Veronika Pistyur, Budapest, 2016).

\section{As Pistyur continues, the founders did not understand that}

while the New York Times writes on Prezi, $\mathrm{HVG}^{6}$ does not, and even if it does, it writes about it only in the Tech section, while the founders believed that these are creative and innovative companies which could work as an engine for an economy (Pistyur 2016).

Therefore, the initial motivations arose from the difference the startuppers felt between their attitudes and that of the rest of the country, and from the country's incomprehension towards the economic role of startups and other creative and innovative companies.

Bridge Budapest currently has four programmes: Bridge Basics, My First Million, Bridge Budapest Fellowship for Talents and Bridge Builders. Besides these programmes, since 2013 Bridge Budapest has conducted a representative, telephone-based survey every year in collaboration with Kutatólabor, a marketing research agency, in which they are investigating the work values, entrepreneurial inclination and future career plans of the 20-35 year-old generation. ${ }^{7}$

${ }^{6}$ HVG (in English): is the most important Hungarian weekly economic and political magazine.

7 The results of the survey are not public; however, Veronika Pistyur sent me the résumé, made by Kutatólabor. 
NEW SPIRIT AND NEW HERO: HOW HUNGARIAN STARTUPS REDEFINE THE IDEAS OF LOCAL CAPITALISM

\section{Theoretical Considerations}

The theoretical starting point of my research is the axiom of the inseparability of economic systems and the ideologies that justify them (Boltanski and Chiapello, 2007), and my inquiry will focus on this relation in the case of the Hungarian startup companies. However, I do not aim to create a generalized description of the spirit of capitalism, as Luc Boltanski and Ève Chiapello did in their seminal work, The New Spirit of Capitalism (2007). In this book their attempt was to theorize the changing spirit of the French variety of capitalism, but besides this their unconcealed aim was to describe the general tendencies of the corecapitalist countries. They assume that in the core-countries of the world economy, capitalism has a general, widely accepted societal representation, which despite its temporal and spatial limits can be described as a spirit accepted by many. This approach is well represented in their concept of ideology. According to them, ideology is embedded in institutions and actions, and is a widely shared set of experiences and beliefs. They argue that ideology is not about oppressive social relations, but everyone, both the weak and the strong "rely on these schemas in order to represent to themselves the operation, benefits and constraints of the order in which they find themselves immersed" (Boltanski and Chiapello, 2007: 10-11). Therefore what results from the concept of ideology used by Boltanski and Chiapello is that the representation of capitalism is uniform for the majority of society, regardless of social position or any particular context.

In my own research I do not aim to describe the general representations and spirit of the Hungarian variety of capitalism; rather, I will interpret the activities of the Bridge Budapest Association as an attempt to establish a new spirit, a new representation of capitalism in the Hungarian context. However, this angle makes it necessary to rethink the concept of ideology used by Boltanski and Chiapello too. In their approach the ideologies justifying capitalism are not the products of any single class or group, therefore they are not connected to any purposeful actor. However, in this case, as we are talking about an attempt to establish a new spirit of capitalism in the local context, the ideologies and the content of this new spirit will be the discursive product of a specific group.

Due to the theoretical problems discussed above, I use Karl Mannheim's programme of the sociology of knowledge. In Mannheim's sociology of knowledge the particular and situationally determined nature of any point of view has a central role (Mannheim, 1998). Therefore I argue that the ideologies of the new spirit of capitalism are also situationally determined and particular. ${ }^{8}$ This argument

${ }^{8}$ In this case I am not using 'particular' in the sense of the mannheimian concept of particular ideology, that is, not as an expression concerning the critique of ideology, but rather as the foundation of his programme of the sociology of knowledge, according to which all points of view are particular, that is ideological. 
theoretically strengthens my approach, according to which the attempt to establish this new spirit is connected to a specific group, and the ideologies of this new spirit are their discursive products. This specific group is formed by the members of the Bridge Budapest Association, by the loosely connected startuppers, journalists, and by anyone approached and convinced by the Association. However, the use of Mannheim's concept implies that due to the situationally determined and particular nature of ideologies, in the Hungarian context only a small part of the society will imagine capitalism according to the new spirit. The overlap between them and the producers of this ideology, that is the circles of Bridge Budapest, is hardly measurable. Nevertheless, I argue that even though these ideologies are particular and situationally determined, as their objective is to establish a new spirit, they are aspiring for universality, for a status, in the frame of which they could serve as the justifications and representations of capitalism for the whole society.

Besides the elaboration of the content of the new spirit and the concept of ideology, one should also consider the local context in which the establishment of the new spirit is taking place. Whereas I agree with the argument of Fourcade and Healy (2007) that markets are more than economic systems as they are always relying on, and are universalized by a moral order, we should also pay attention to the local particularities of these regimes. While Boltanski and Chiapello elaborated their theory in a core-capitalist country (Boltanski and Chiapello, 2005), Bridge Budapest functions in the semi-peripheral Hungary (Éber et al., 2014). This divergence raises the question whether it is possible to identify the core, the semi-periphery and the periphery of the world system according to nation state borders, if these concepts represent most of all relations of production processes and not states. However, as far as the state is concerned, these concepts refer to the expression of the hierarchical global division of labour as reflected on the level of the national economies and state infrastructures (Éber et al., 2014). Therefore, even though capitalist production does not function according to national borders, the state works as an organization that in a certain area provides infrastructure and legal framework for capital, and thus the inequalities produced by the world-system appear within its reach.

Unit of analysis will also be the state, because the Association's programmes aim to develop the Hungarian national economy. Positioning the Hungarian state within the world-system is necessary, because Bridge Budapest aims to help the country catch-up within the global division of labour. However, the Association does not primarily imagine this catching-up through changing the composition of the Hungarian economy or the economic policies, but rather through shaping the attitudes and ideologies of the Hungarian society. For this reason I will engage with the concept of semi-periphery not in an economic sense, but as related to the ideology of catching-up attached to it (Böröcz, 2012). 
Nevertheless, world-system theory's original economic focus is also important to understand the idea of development, as it shows the economic context and the global division of labour in which the ideology of catching-up is rooted.

\section{Talking of business, silencing politics: the construction of the entrepreneur, society and politics in the discourses of Bridge Budapest}

According to my interviews, I classified the three central objectives of Bridge Budapest, as (i) shaping the entrepreneurial thinking (or as my interviewees said, the entrepreneurial mindset), and the attitudes of Hungarian society towards entrepreneurship; (ii) shaping the social context of the enterprises, and (iii) help the country catch up. In the following I am going to examine Bridge Budapest according to these objectives, and I will embed their projects into these categories.

\section{Bridge Budapest and the making of the entrepreneur hero}

The first objective that I investigate is the shaping of the entrepreneurial thinking, and of the attitudes of Hungarian society towards entrepreneurship. This objective appears in My First Million, just as in Bridge Basics, in Bridge Budapest Fellowship for Talents, and also in the researches of the Association, thus it can be argued that it is one of the most important objectives of Bridge Budapest.

In My First Million Bridge Budapest conducted a research with the Kutatólabor agency to examine the values Hungarian society associates with entrepreneurship. The research was entitled Two faces of the Hungarian entrepreneur: The hardworking innovator and the cheater (Első millióm, n.d.). The conclusion of the research, in accordance with its title, was that in Hungarian society there are two representations of the entrepreneur:

\footnotetext{
on the one hand the image of the cheating, gangster-entrepreneur, who is driving luxury cars and is looking for loopholes is still in the minds of people, but on the other hand the image of the creative, innovative and courageous entrepreneur is already spreading, primarily in the younger generations (Első millióm n.d.).
}

It is worthwhile to focus on the temporal placement of the two entrepreneur-images: the cheating, gangster-entrepreneur is located in the past by the phrase is still in the minds, while the image of the creative, innovative and courageous entrepreneur is already spreading thus it is located in the present and in the future. In this sense the phrase already spreading refers to the expansion 
of the representation of capitalism that the Bridge Budapest considers desirable, but which is still incomplete. Hereupon, the chief goal of My First Million is to change the representation of the entrepreneur, the key figure of capitalism, within the local context. The programme positions itself against the image of the cheating entrepreneur, and aims to associate the image of the entrepreneur with the values of creativity, innovation and courage.

At the same time Bridge Budapest aims to realize this goal by tutorial videos, targeted to entrepreneurs. Thus the Association is not only trying to change the image, but also the practice of entrepreneurship. Part of this project is the spreading of the idea of ethical entrepreneurship by videos on entrepreneurs' stories about their first million. As Csaba Faix says,

there is a saying that one should never ask an entrepreneur about their first million, because after that every company has en excellent pedigree. But we were looking for entrepreneurs, who were ready to talk even about their first million, by saying that 'I had an idea, a team', or anything else that makes the story transparent (Interview with Csaba Faix, Budapest, 2016).

Therefore the concept of ethical entrepreneurship on the one hand means transparency, and on the other hand it also means, as Balázs Varró says, that 'you should accept the legal frames and regulations in which you run your business' (Interview with Balázs Varró, Budapest, 2016). By the idea of ethical entrepreneurship, in the Bridge Budapest's imagination the entrepreneur becomes the central figure of the Hungarian public sphere as the driving force of the economic and social development. According to Bridge Budapest, ethical entrepreneurship contributes to the development of the country in three ways: by improving its competitiveness, by developing infrastructure and by making the local enterprises more successful.

As a consequence, we can understand My First million as the foundation of Bridge Basics: My First Million is not only targeting entrepreneurs, but also potential entrepreneurs and the wider public, for which the image of the entrepreneur should be changed. In contrast with this, Bridge Basics is targeting those who already have specific problems with launching an enterprise. However, as Bridge Budapest's aim is to promote the idea of entrepreneurship, the representations produced by Bridge Basics and by My First Million should be seen not as conflicting, but as complementary. Bridge Basics offers a more concrete know-how for the ideal entrepreneur and enterprise, while My First Million approaches it primarily from an ethical angle. The specific entrepreneurial culture and know-how promoted by Bridge Basics nevertheless cannot be separated from the idea of ethical entrepreneurship, and my interviewees argue that Bridge Basics presents the corporate culture that is arising from ethical entrepreneurship. 
As Csaba Faix argued, 'when I develop a software for all the users of the world, I cannot corrupt anyone, because I am judged only by the market' (Faix, 2016). According to Veronika Pistyur, the tutorial videos of Bridge Basics are showing the corporate culture of the founding companies of Bridge Budapest (Pistyur, 2016). The goal of this programme is knowledge transfer, and the promotion of the corporate culture of Prezi, Ustream, LogMeIn and NNG. Pistyur states that a central characteristic of these corporate cultures is that 'they are thinking about their employees in an ethical way' (Pistyur, 2016); however, in what follows I will argue this is not only for moral reasons, but also serves the productivity of the companies.

The image, emerging from Bridge Budapest's tutorial videos and from my interviews, shows several similarities with the spirit of capitalism that Boltanski and Chiapello name as the projective city. In the description of the spirit of capitalism Boltanski and Chiapello use the concept of the city (cite), which was developed by Luc Boltanski and Laurent Thévenot in their book On Justification (2006). The concept of city is important for Boltanski and Chiapello inasmuch as it functions as a normative support for the ideologies which are justifying capitalism. Boltanski and Chiapello link the projective city, the new form of capitalism that is based on new justifications and on methods of organizing work, to the neoliberal turn that was preceded by corporate capitalism that flourished from the 1930s until the 1960s in the Western World. In Hungary corporate capitalism has never existed, but the discourses of new capitalism can nevertheless arise, because the initiating startup companies are embedded into global networks and are producing for global markets. For example Balázs Varró says that for Ustream the role model regarding corporate culture is Silicon Valley (Varró, 2016).

The corporation remains one of the key institutions in the projective city, yet this is not the hierarchic corporation of corporate capitalism any longer, but instead the lean firm that organizes work in autonomous, flexible and adaptive teams (Boltanski and Chiapello, 2007). Adaptability as a crucial characteristic of enterprises was also emphasized by Veronika Pistyur, who linked it to the global technology market, where fast response time is crucial (Pistyur, 2016). Boltanski and Chiapello are referring back to the roots of this approach when they are highlighting that the discourses on adaptation appeared in the managementliterature of the 1990s and became important because of the intensification of global competition (Boltanski and Chiapello, 2007). For proper adaptation to the changing environment, it is not only the destruction of the expensive hierarchies that is critical, but also the establishment of a new corporate culture, based on new motivations and justifications. 
According to Boltanski and Chiapello, the critique of hierarchies emerges from the criticism of the bureaucratic nature of corporate capitalism. However, the dismantling of hierarchical control gives space to new forms of discipline, such as market-based control, which forces companies and employees towards higher adaptability. This resonates with the words of Csaba Faix, who argues that 'we are trying to build Prezi as a big startup, in which many small startups are operating, thus we are trying to preserve the flexibility and ownership that we had at the beginning' (Faix, 2016). Faix links flexibility to the small, autonomous teams working within the company, and according to Boltanski and Chiapello the idea of autonomy has the function of providing the moral justification for market-based control. They argue that the cessation of the hierarchical control led the managers towards looking for new corporate control mechanisms. Due to fact that market control did not offer enough motivation for employees, there was a need for introducing new, moral and psychological motivations (Boltanski and Chiapello, 2007). In the management-literature the higher degree of autonomy is a form that allows the non-hierarchical self-realization of the employees (Boltanski and Chiapello, 2007). Gergely Hodicska, Ustream's Vice President of Engineering argues similarly when talking about the motivation of employees. He defines motivations as internal factors, which are more important than the external ones, such as money. According to Hodicska, autonomy is one of the factors of motivation that makes possible to give employees problems to solve, rather than simple tasks (Bridge Basics, 2015). Csaba Faix also emphasizes autonomous problem solving as a motivating factor:

\footnotetext{
if there is a task or a problem we do not tell the team, or the engineers working on it to code Prezi in this way, or to do this task, or to write this down, because that would fit more or less to a semi-skilled job. We rather say that we want Prezi to be better in this and that (Faix 2016).
}

This network of unstable relations is called by Sennett 'concentration without centralization', after Bennett Harrison, and he argues that the freedom of this model is only seeming, because the fall of bureaucracy does not mean less institutional structure, but rather the establishment of a new, more complex, but not pyramid-type structure (Sennett 1998: 55-57). According to the startups, these changes make work more creative and give space for one more internal motivational factor, which, according to Hodicska, is the sense of self-development (Bridge Basics, 2015).

Autonomy and self-development as motivational and justifying factors are fostering self-control (Boltanski and Chiapello, 2007), therefore self-control within these enterprises functions as a complement to market-based control. Besides autonomy and self-development, the atmosphere of trust also plays a crucial role 
in the implementation of self-control. According to Boltanski and Chiapello 'trust is in fact the other term for self-control, since it designates a trustworthy relationship where the only mechanism that exists is the pledged word and moral contract' (Boltanski and Chiapello, 2007: 83). Trust builds the team, strengthens the ties between employees and managers, and because it is a moral question, it makes work a matter of conscience. The importance of trust is also emphasized by Rita Hambalkó, Prezi's former Recruitment Manager, in a tutorial video made for Bridge Basics. She argues that trust is required for the liberty that Prezi offers to employees in the form of flexible working hours and the lack of other direct bureaucratic controls. According to her 'if we give liberty, responsibility and trust, people will be motivated in their work' (Bridge Basics, 2015). Gergely Hodicska mentions trust as the most important part of corporate culture too, the base of cooperation that facilitates experimentation and innovation on the part of the employees (Bridge Basics, 2015). Due to the atmosphere of trust, in the corporate culture of these companies interpersonal relationships are re-evaluated and appreciated (Boltanski and Chiapello, 2007). While the previous spirit of capitalism with the help of rational calculations aimed to rule out personal relations, personality and charisma from recruitment and promotion in the name of fairness, in the new spirit personality and personal relations are becoming important (Boltanski and Chiapello, 2007). As Veronika Pistyur argues,

performance and knowledge have an exponential value. Thus neither from me, nor from many other employees was any certificate required, because it is not the certificate, but rather face-to-face situations, problem solving abilities, and reactions to certain situations that matter (Pistyur, 2016).

From this quotation we can see that the emphasis is not on objective criteria, but on personality, attitude, performance and knowledge. However, these are not measurable in the traditional way through certificates, but are perceptible only through personal relations.

Personal qualities are not less important in the case of managers and entrepreneurs either. According to Boltanski and Chiapello, in the projective city successful people should be charismatic, able to motivate others and should have a vision that is convincing enough to be followed by employees. These abstract qualities are strongly present in the tutorial videos of Bridge Basics. As Péter Halácsy, the co-founder of Prezi says, as successful leaders they should not dictate the direction, but rather motivate employees and 'help others to create the product, the business' (Bridge Basics, 2015). Veronika Pistyur formulated it similarly by distinguishing two management models:

A leader just stands at the top and waits for the employees to follow him/her, or stands at the bottom and pushes and helps to create an atmosphere and environment for employees in which they can fulfil their own potential (Pistyur, 2016). 
Besides motivation, Gergely Hodicska highlights the importance of the vision, and argues that leaders should provide an objective for the employees, for example the idea of making the world a better place (Bridge Basics, 2015). As Péter Halácsy states in one of the tutorial videos, 'think about the long term goal, the mission of your organization that should be realized and tell it to everyone, put in on your website' (Bridge Basics, 2015). In contrast with Halácsy or Hodicska, Ádám Somlai-Fischer, the co-founder of Prezi, does not refer to the mission as a factor of the motivation of the employees, but instead takes the role of the inspiring, visionary leader by stating that in designing a product it is not worth to focus on the problems to be solved but it is better to imagine 'an inspiring future that we desire', because the product will be part of a lot of people's lives (Bridge Basics, 2015).

The ideas examined above, such as autonomy, trust, self-development and interpersonal relations are functioning as psychological motivation within the projective city because they are breaking with the alienated work that characterized corporate capitalism and was based on hierarchy and rational calculation. The visions of the leaders, the image of the inspiring future, of a better world, or any other mission can function as a psychological motivation that is able to strengthen the internal cohesion of the company and to give meaning to work. Moreover, these ideas are also justifying the projective city from the perspective of the common good, because the goals set can be social ones, as Hodicska emphasizes. In the projective city another form of referring to the common good is the justification of market control by emphasizing the primacy of consumers. According to this argument, the primary goal of companies is to serve consumers, thus the real control should be removed from managers and given to consumers themselves (Boltanski and Chiapello, 2007). In this discourse the company serves the consumer, and this makes necessary the continuous adaptation to the consumers' demands, thus to a higher degree of market-based control. Gábor Vészi, Prezi's former Director of Engineering, in his tutorial video uploaded to the site of Bridge Basics emphasizes exactly these standpoints. According to him, in the product design consumer feedback is crucial because this guarantees the success of the product and the satisfaction of the consumers (Bridge Basics, 2015).

In the discourse of Bridge Budapest the references to the common good appear also from the perspective of the social and economic development, as we also see in the case of the ethical entrepreneurship. This image of the enterprise is present in Bridge Basics too. The techniques of motivation appearing in the tutorial videos, such as the autonomy of employees, the opportunity for selfdevelopment, trust and the primacy of consumers, are not self-serving, but are fostering a higher degree of market-adaptation, and therefore 'productivity, 
creativity and innovation' (Pistyur, 2016). According to the discourse of Bridge Budapest, these are important for the success of the company and crucial for the competitiveness of the country at the same time. As Pistyur formulates it, 'creative and innovative companies can serve as an engine of the economy, and from the perspective of the country it is important how many of these do we have' (Pistyur, 2016). According to Faix

Hungary can stay in competition with the world if it creates companies based on ideas like this. It is clear that Hungary does not have oil reserves or any natural resources on which it could build on, or any traditional industry, but the ideas, like Prezi, are available to us as well (Faix, 2016).

My First Million's representation of the entrepreneur who contributes to economic development by ethical entrepreneurship is supplemented by the perspective of creativity, innovation and idea in Bridge Basics. Therefore Bridge Basics represents the ideal Schumpeterian entrepreneur. According to Joseph Schumpeter, the most important characteristic of an entrepreneur is innovation: the entrepreneur introduces new products, new production methods and new industrial organizations (Schumpeter, 1928). In Bridge Basics' tutorial videos, the innovative activities of the entrepreneur appear in the designing of new products and in the introduction of new, creative organizational cultures that in the local context count as innovative too. As Schumpeter argues, the most important consequence of innovation is that the previous equilibrium of the economy changes, which leads to economic development (Schumpeter, 1928). We can observe the same approach in the interviews analysed above, in which interviewees evaluated idea, innovation and creativity as the keys of Hungary's competitiveness.

According to Schumpeter, economic development needs figures who can break with the previous economic practices and can recognize the new opportunities (Schumpeter, 1982). The break with the previous practices in the narrative of Bridge Budapest appears as 'risk-taking'. In the research that Bridge Budapest and Kutatólabor conduct every year, they argue that risk-taking is the precondition of innovation and creativity. The research confronts employee-existence with autonomous existence, and extends this dichotomy to the opposition of the boring, but safe work versus the risky and joyful one, and to the average salaries of the employed versus the high, but uncertain incomes of the entrepreneurs. Thus boredom, safety and average incomes are becoming the epithet of employee status, in contrast with the joyful, risky and autonomous life of the entrepreneurs that offers high but unpredictable incomes. According to the analyst of the research, choosing the latter option signals the risk-tolerance of the respondent. According to Balázs Varró today risk-tolerance is very low, 'in Hungary the frustration 
after a failure lasts for a lifetime, while in the US, where from ten attempts only one works out, people try for the ninth time too' (Varró, 2016). The positive framing of risk-taking, such as its association with enjoyable work, also contributes to the image of the entrepreneur that Bridge Budapest is building. On the one hand risk-taking increases the positive aura of the entrepreneur by emphasizing its sacrifice. Thus entrepreneurs are not only creating new products and functions as the engines of the economy, but they do this with an incredible courage. Moreover, by promoting the merits of risk-taking, uncertainty and instability not only for entrepreneurs but for the whole society, Bridge Budapest extends the characteristics of the Schumpeterian entrepreneur to the ideal Everyman of the present, just as Sennett argues (1998).

From another perspective we can also understand the discourse on risktaking as a meritocratic element that justifies the entrepreneurial success by linking it to sacrifice. This aspect is called by Boltanski and Chiapello the 'formula of investment', and according to them all the regimes of justification need something like this to maintain the semblance of truth (Boltanski and Chiapello, 2007). Therefore, according to Bridge Budapest the entrepreneur should take uncertainty and the risk of failure to achieve success, since this is the way that leads from the boring to the inspiring and creative work.

By concluding the analysis of Bridge Budapest's representation of the entrepreneur, I argue that the Association tries to change entrepreneurial thinking and the image of entrepreneurship in the Hungarian context on a number of fronts. The entrepreneurs of Bridge Budapest are ethical, creative, innovative and risk-taking heroes. They are responsible for the good mood in the workplace, for their employees, and even for the country's welfare. They break with the attitudes of the cheating entrepreneur and with the paternalistic approach of the Hungarians, they are not afraid of failure, and they do not look for safety. Therefore Bridge Budapest not only changes the image of the entrepreneur, but also sets it as a role model for Hungarian society: the model of the perfect moral and economic subject.

\section{Bridge Budapest as a technocratic post-political project}

Among the programmes of the Bridge Budapest Association, Bridge Builders is the only one that is not focusing on the enterprise and on the entrepreneur. In this programme the Association invites ten people in their late twenties or early thirties, who are considered as influential opinion leaders in their own fields. According to Pistyur, Bridge Builders focuses primarily on the social context of entrepreneurial thinking. As she argues, 
NEW SPIRIT AND NEW HERO: HOW HUNGARIAN STARTUPS REDEFINE THE IDEAS OF LOCAL CAPITALISM

an enterprise is not understandable without its environment. We can try to do anything for change, but if people at the executive levels of different fields of society do not understand these ideas that are important for us, decisions will be made without seeing through these questions (Pistyur, 2016).

Thus the goal of Bridge Builders is to change the social context of the enterprise, and to help the diffusion of the Association's ideas and values in society.

Bridge Builders consists of five weekends of workshops in Hungary, and one in Sweden. During these weekends Bridge Budapest offers leadership training for the participants to make them better leaders (Pistyur, 2016). According to Pistyur, in these trainings

we are trying to improve the interrelations of the individual and the world, for which a high degree of self-awareness, self-knowledge and vulnerability is needed. We also believe in many other things that could make someone a better leader. We are trying to inspire the participants to embrace these ideas through different practices (Pistyur, 2016).

Bence Tordai, one of the selected participants, recalls the structure of the weekends:

On the first days there were guest speakers from the Board members of Bridge Budapest, who are successful leaders, and they highlighted important aspects through their own stories. They also brought us related practices about how to relate to your own life by looking back from a hypothetical endpoint, about how to create something from nothing and about the function of interpersonal relations in these processes. On the second weekend there were coach-led tasks [...] The essence of it was to make us freer by choosing an appropriate position and approach with which we can handle a problem or a situation. And this was the gist, the multiplication of our potency (Tordai, 2016).

According to Tordai, the coaching focuses on the structuring of the situations which participants regularly encounter, and on the reflection on and change of their own roles in these situations. As an example, Tordai mentioned that when a leader prefers battles and consequently has many conflicts, it is probable that these conflicts are generated by the leader himself/herself, thus he/she can also work against it (Tordai, 2016).

Although the trainings had a micro-level focus, such as the relation of the self and the world, self-development in decision making, and development of problem-solving skills, Bridge Builders also has a macro-level mission. The mission of the programme is to 'empower Hungary's future leaders to inspire and build a Hungary that is proud of its achievements and knowledge' (Bridge Budapest, n.d.). Achievement and knowledge are the key elements of Bridge Budapest's social vision, in contrast with the attitudes of the present-day Hungary, where, according to them, personal relations are too important, and the success is linked to cheating. As Pistyur argues, 
researches shown that luck, political connections and personal relations in general have an exponential appreciation in the system and in attitudes, and these are obstacles for someone to believe that they can start a successful enterprise, although the global market is an evidence that it can be done with knowledge and performance too (Pistyur 2016).

Since in Bridge Basics the changing of the social environment appears as the shaping of the entrepreneurship's context, for its success the meritocratic myth of the entrepreneur and the enterprise should be shared by the wide society. Meritocracy justifies the differences in social status with the principle of performance, thus it is an appropriate concept to justify the higher status of entrepreneurs too (McCoy and Major, 2007). As Balázs Varró stated, the mission of the Association is

to show what can be achieved with great ideas, entrepreneurial attitudes, and of course, with hard work, because it was never a secret that the idea is not enough in itself, the major part is work and teamwork (Varró, 2016).

Besides the emphasis on hard work, a further meritocratic element is the association of risk-taking attitudes to entrepreneurship. However, while risk-taking is the 'formula of investment' that is directly associated with the figure of the entrepreneur, performance and knowledge, arising from hard work are broader principles, which are valid beyond the economic sphere. According to Tordai the mission of Bridge Builders is to change the Hungarians' attitudes towards success 'to make us believe that we are able to create things and to make a hit', to popularize a positive approach that states that hard work will pay off (Tordai, 2016). Thus meritocracy justifies the success of the entrepreneur and the establishment of the uneven social statuses, and at the same time, according to Bridge Budapest, fosters success by giving confidence to the ones who have knowledge. This attitudinal change is intended to create a business-friendly social environment, thus it is a precondition for the realization of Bridge Budapest's further goals, such as economic well-being or keeping of the Hungarian graduates in the country (Varró, 2016).

The shaping of the social environment, namely the building of a knowledge and performance based society, is imagined by Bridge Budapest in a networked structure. The Association distinguishes five important social spheres, which are covering the society and which they consider as important. These fields are media, politics, economics, NGOs, and the cultural sphere (Pistyur, 2016). However, the Association does not aim to directly address a wider audience connected to these spheres, only its young leaders. According to Faix the goal is 'to find those 30-31-year-old people who within 10-15 years are going to be 
among leaders of the country in a political, economical or academic sense' (Faix, 2016). 'When selecting these young opinion leaders we pay attention to represent all the five spheres' (Varró, 2016). According to Pistyur, 'if they [the young leaders] start to work, to make decisions, to build organizations, to take positions, to cooperate differently, it will create a network within the system' (Pistyur, 2016). Therefore Bridge Budapest divides society into coequal spheres, and imagines social change through a network that interlaces them. Henceforth, the Association represents society as a network that is similar to the representation and logic of society in the projective city (Boltanski and Chiapello, 2007). It is an exciting contradiction that while according to Bridge Budapest a meritocratic society should reject the importance and use of personal relations for any goal-oriented reason, they see that this society can be established only through an interpersonal network. However, the idea of the network, the myriad of weak ties, is not only the central characteristic of Bridge Budapest's vision, but also more generally, as Richard Sennett argued, of New Capitalism. He emphasizes that while corporate capitalism was based on strong ties and long term employment, the current one is typically based on the greater number of weaker ties (Sennett, 1998). This web, built in Bridge Builders, is not only the network of young leaders, but functions also as the network of the Association, because by coaching these opinion leaders they can find valuable partners in several parts of society. Besides these, it can be argued that the network-logic is a technocratic-logic: the idea of the society that can only be addressed through opinion leaders splits society into leaders and followers, moreover imagines social change only in a top to the bottom way.

The knowledge that Bridge Builders aims to give to the selected leaders is openly technical and apolitical. According to Russel Prince the definition of technocracy includes that its knowledge is apolitical, rational and technical (Prince, 2015). Bridge Budapest, apart from a certain level of (social) psychology, does not aim to pass on theoretical knowledge; rather, it focuses on decisionmaking and on the techniques of implementation. According to Faix,

[the programme] is not about the economic concepts along which a company should be led, no, it is about what to say to people to empower them to solve problems... Here we help these people to make better decisions, to understand a problem, to involve new angles in problem-solving. Thus it is not a theoretical training (Faix, 2016).

The main selection criteria for Bridge Builders are that each participant should be an influential and good professional in their own field. According to Varró,

as an impartial organization our unconcealed aim is to express that we are inclusive. Thus for us political positions do not matter if someone is a great chat partner, a good professional, it does not matter for whom they will vote (Varró, 2016). 
However, this self-proclaimed ideological neutrality still leads the Association to pay attention to the ideological diversity, and not only to professional qualities, during the selection process. They select the participants 'from the most different professions and from the most different political and ethical valuesystems' (Varró, 2016). As Faix stated, their goal with this conscious selection is

to make these people realize - while there are still no power-constructions between them that would hinder dialogues - that there are more things that bind them together than those that separate them (Faix, 2016).

Consequently, the programme is not only apolitical, but goes beyond politics with the help of instrumental rationality, thus it is post-political. According to Varró, politics just hinders higher purposes:

We should show them that "hey guys! you are not enemies, but partners in certain things". Because probably I am not the only one who sees that people's thinking, their political orientation hinders cooperation and higher purposes than the individual ones (Varró, 2016).

This quotation clearly demonstrates that in Bridge Budapest's approach these higher purposes are not ideological, but rational objectives, superior to political ideologies. Consequently, the achievement of these can only be possible with an advanced technical and goal-oriented knowledge, but this requires consensus and the cooperation of experts and leaders. If we use the term of politics following Jacques Rancière, it can be argued that even the objectives of the programme are not political ones (Rancière, 2004). According to Rancière politics is about the formulation of common issues and objectives, and not about the execution of the objectives, set by a group of experts. He argues that politics is not a struggle over the solution of a situation, but a debate over the meaning and interpretation of it, and about the question of what is the situation that should be solved (Rancière, 2004). In the programmes of Bridge Budapest the higher purposes, such as economic well-being, the future opportunities of the young generation or the meritocratic society are already set, and there is no space for politics, namely for the disagreement about the situations and the goals. This way, the assigned objectives are not political, but are reduced 'to the management of the local consequences of global economic necessity' (Rancière, 2004: 4). This referencing to the necessities is able to justify the pre-setting of objectives and the importance of consensus. Although in the discourses of Bridge Builders little is said about necessities, their goal is to shape the social context of the enterprise, and thus the support of goals stems from economic necessities, such as the improvement of the country's competitiveness and economic development. Faix underlines the most important goals in this spirit by saying that 
NEW SPIRIT AND NEW HERO: HOW HUNGARIAN STARTUPS REDEFINE THE IDEAS OF LOCAL CAPITALISM

there are fundamental questions that we should discuss, independently from the current regime. For example, the question of how to encourage innovation, what kind of business-friendly environment we support, or what type of programmes we are launching to help businesses to enter the European market (Faix, 2016).

Therefore, according to Bridge Budapest, in the setting and the execution of the goals there should be an unquestionable consensus, that in Rancière's interpretation bears the technocratic dream of hoping that conflicts over the 'common' and consequently the political can be eliminated as outdated ideologies (Rancière, 2004).

\section{Conclusions: Strategies of moral and economic catching-up on the semi-periphery}

In this article I investigated the relation of the Hungarian startups to their local environment through the inquiry of the discourses of Bridge Budapest that is founded and funded by the most important Hungarian startups. In answering my research questions I argued that their discourses on the ideal society and capitalism are technocratic and post-political attempts for the establishment of a new spirit of capitalism. The Bridge Budapest Association in the Hungarian context aims to change the representation of the enterprise and the entrepreneur, the central institution and figure of capitalism. Therefore their aim is to make the new spirit of capitalism universal and obtain a status for it that could (re)justify the enterprise and the entrepreneur for Hungarian society.

However, this attempt for establishing a new spirit is neither self-serving, nor happening in a neutral space, but it aims to change the country's position, to help it catch-up in the hierarchy of global capitalism. Economic catching-up in this context means both the improvement of competitiveness and the expansion of the technological and creative sectors, typical in the core countries. As Faix stated, 'we want to put Budapest on the startup map, next to London, Stockholm, Berlin, Barcelona and Tel Aviv. This is our goal, to be the most important hub in the region in the first step' (Faix, 2016). Consequently, the role model of the catching-up is Silicon Valley, which carries the spirit of the projective city that I presented in the section on Bridge Basics. The other example is Estonia, famous for its startups, and where economic dynamism, according to Pistyur 'can be dated back to the success of Skype' (Pistyur, 2016). However, for the catching-up Bridge Budapest does not offer a programme of economic policies, but instead aims to shape the ideas on and attitudes towards the enterprise and capitalism. Therefore, according to them, the final objective, the economic catch-up, could be achieved through a moral and attitudinal catch-up. They consider necessary for the moral catch-up the spreading of the idea of ethical enterprise, and for the attitudinal catch-up the increase of risk-taking and the change of the Hungarians' 
paternalistic attitude. Besides these, their goal is the establishment of a meritocratic society, where 'that is proud of its achievements and knowledge' and not of the achievements through (political) relations (Bridge Budapest, n.d.). Meritocratic society, attitudes and moral change are all imagined in the context of the enterprise, and their objective is the formation of an entrepreneur and enterprise-friendly society. In this context the central figure of the catch-up is the entrepreneur, who as a Schumpeterian innovator contributes to the expansion of the creative and technology sectors and to the improvement of the country's competitiveness (Schumpeter, 1928). This frame provides additional justification for the entrepreneur, because it presents him/her as an essential figure of the common good.

In the narrative of Bridge Budapest the formation of a business-friendly environment that indirectly contributes to economically catching-up, appears in a technocratic post-political frame. This is visible primarily in Bridge Builders, which aims to shape the social environment only in a top to the bottom way, through the young opinion leaders. Therefore this programme tries to establish a network of the leaders of the future that bridges ideological breaks and is able to create a social environment in which there are no competing political goals, but everyone works for the commonly shared objectives: for technological knowledge, for positive entrepreneurial attitudes, for a business-friendly environment and for the catching-up of Hungary. This is the essence of the Bridge Budapest's post-political ideology: in the context of their programmes, politics does not disappear, but the subject of real political disagreement, namely the question of what kind of world we want to live in, is being formed into an unquestionable consensus.

Nevertheless, Bridge Budapest not only aims to change society and to (re)justify the enterprise and the entrepreneur, but more specifically intends to justify the Hungarian and the international startup scene. By stating that they are working for the transparency of economic life, for real market competition, for the catching-up of the country and even for the introduction of a new, more exciting and flexible organizational culture, startups are appearing as the bearers of the moral and economic principles and practices that can be exemplary for everyone. Therefore startups and startuppers are taking the burden of the new spirit of capitalism and and are presented as the perfect subjects of catching-up. It is not accidental that selected young leaders in Bridge Builders are trained and taught directly by the CEOs of the startups, because according to Bridge Budapest startups are the organizations that could function as role models for the other spheres of society. Consequently from the perspective of Bridge Budapest the startup scene is the complex of the perfect economic and moral subjects, for whom the shaping of the local society is more than an opportunity, it is a duty. 
NEW SPIRIT AND NEW HERO: HOW HUNGARIAN STARTUPS REDEFINE THE IDEAS OF LOCAL CAPITALISM

\section{REFERENCES}

Boltanski, L., Chiapello, È. (2007 [1999]). The New Spirit of Capitalism. New York: Verso. Boltanski, L., Thévenot, L. (2006 [1991]). On Justification: Economies of Worth. Princeton: Princeton University Press.

Böröcz, J. (2012). Hungary in the European Union: 'Catching Up', Forever. Economic \& Political Weekly, 47(23): 22-25.

Éber, M., Gagyi, Á., Gerőcs, T., Jelinek, Cs., Pinkasz, A. (2014). 1989: Szempontok a rendszerváltás globális politikai gazdaságtanához [Viewpoints for the global political economic analysis of the regime change]. Fordulat, (21): 11-63.

Fourcade, M., Healy, K. (2007) Moral Views of Market Society. Annual Review of Sociology, 33: 285-311.

Mannheim, K. (1998 [1929]). Ideology and Utopia. London: Routledge.

McCoy, S.K., Major, B. (2007). Priming Meritocracy and the Psychological Justification of Inequality. Journal of Experimental Social Psychology, 43(3): 341-351.

Prince, R. (2015). The Spaces in Between. Mobile Policy and the Topologies and Topographies of the Technocracy. Environment and Planning D: Society and Space, 34(3): 1-18.

Rancière, J. (2004). Introducing Disagreement. Angelaki. Journal of Theoretical Humanities, 9(3): 3-9.

Schumpeter, J. (1928). The Instability of Capitalism. The Economic Journal, 38(151): 361-386.

Sennett, R. (1998): The Corrosion of Character. The Personal Consequences of Work in the New Capitalism. New York and London: W. W. Norton \& Company.

Wallerstein, I. (2004). World-systems Analysis: An Introduction. Durham and London: Duke University Press.

\section{Online Sources}

Bridge Basics (2015): Gyors iterációkra fókusz: learnings/day maximalizálása - Vészi Gábor, Bridge Basics.

https://www.youtube.com/watch?v=qgXkMh_iGk (Accessed: 10 April 2016).

Bridge Basics (2015): Hogyan tudom motiválni az alkalmazottaimat? Hodicska Gergely, Bridge Basics.

https://www.youtube.com/watch?v=vzX57bE28YE (Accessed: 10 April 2016).

Bridge Basics (2015): Miért a csapatoddal és ne a termékeddel törödj elsősorban? Halácsy Péter, Bridge Basics.

https://www.youtube.com/watch?v=9qJjsLutg4Q (Accessed: 10 April 2016).

Bridge Basics (2015): Miért fontos a vállalati kultúra kiépítése? Hodicska Gergely, Bridge Basics.

https://www.youtube.com/watch?v=Yj3GPCVsKjY (Accessed: 10 April 2016). 
Bridge Basics (2015): Miért nem érdemes a problémákra fókuszálni? Somlai-Fischer Ádám, Bridge Basics.

https://www.youtube.com/watch?v=p450d1AJD5U (Accessed: 10 April 2016).

Bridge Basics (2015): Mitől lesz inspiráló egy munkakörnyezet? Hambalkó Rita, Bridge Basics.

https://www.youtube.com/watch?v=9lQ8TnHRm7w (Accessed: 10 April 2016).

Bridge Budapest (no date): Bridge Budapest Ösztöndíj Tehetségeknek. http://hu.bridgebudapest.org/osztondij (Accessed: 10 April 2016).

Bridge Budapest (no date): Bridge Builders 2014/15. http://hu.bridgebudapest.org/bridgebuilders/2014-2015 (Accessed: 10 April 2016).

Bridge Budapest (no date): Bridge Builders 2015/16. http://hu.bridgebudapest.org/bridgebuilders_2014 (Accessed: 10 April 2016).

Bridge Budapest (no date): Kik vagyunk? http://hu.bridgebudapest.org/kik-vagyunk (Accessed: 10 April 2016).

Első millióm (2015): Miért éri meg vállalható módon vállalkozni? Árvai Péter véleménye. https://vimeo.com/139123014 (Accessed: 10 April 2016).

Első millióm (2015): Történetek. http://www.elsomilliom.hu/tortenetek (Accessed: 10 April 2016).

Első millióm (no date): A magyar vállalkozó két arca: a szorgalmas innovátor és a simlis. http://www.elsomilliom.hu/kutatasok (Accessed: 10 April 2016).

Első millióm (no date): Miért éri meg vállalható módon vállalkozni? http://www.elsomilliom.hu/ervek (Accessed: 10 April 2016).

U.S. Small Business Administration (no date): Startups \& High Growth Businesses. https://www.sba.gov/content/startups-high-growth-businesses (Accessed: 10 April 2016).

\section{Interviews}

Faix, Csaba, Interview by the author, 15 February 2016, Budapest Pistyur, Veronika, Interview by the author, 16 March 2016, Budapest Tordai Bence, Interview by the author, 16 February 2016, Budapest Varró Balázs, Interview by the author, 23 February, 2016, Budapest 